\title{
Is Romania Ready for Adopting Euro?
}

\author{
Mihai Rebiga University “Al.I.Cuza” of Iaşi, Romania
}

\begin{abstract}
The common monetary policy is applyed in all member states of the Economic and Monetary Union (EMU), having a common institutional system, common European currency and system of regulations that helps them coordinate the banking activities in all EMU. The application of this policy has brought remarkable results so far, settling the monetary market in the euro zone. But, the new European Union member states have to apply these common rules and regulations in order for them to accede to EMU, which could produce both positive and negative effects, especially given that most of their economies are not yet ready for this king of changes. It is Romania's situation as well, having had the target set on acceding this by 2014. But is the Romanian economy ready for such a change? And how close is Romania to achieving the convergence criteria?
\end{abstract}

\section{Key words}

Economic and Monetary Union, euro adoption, monetary market, financial crisis, convergence criteria, monetary policy

JEL Code: E58

\section{Introduction}

At the time of inclusion in the community, the medium and long term target of the new EU Member States is to achieve a level of integration as close to maximum as possible, political integration being the main expected purpose of all European countries. But this latter stage has not yet been reached, so monetary integration becomes the intermediate target in order to find a solution for the political integration.

Throughout the paper we shall analyze the opinions of several experts on the introduction of euro in countries that currently enjoy the common monetary policy, effects that were expected before joining the Euro Zone and later effects. We shall also analyze the context of the present Romanian economy, the current financial crisis' effects on the monetary and currency market, inflation and achieving the convergence criteria at this level.

The ultimate goal is to determine whether Romania is ready to introduce the single European currency and thus the common monetary policy implementation and establishment of possible effects that may arise from this, if the National Bank of Romania is ready to go under the tutelage of Central Bank Europe as part and to subordinate its monetary policy and the effects that this might cause the subordination of the fragile Romanian economy.

For this, the paper is structured as follows: Section 2 presents the current context of the Romanian economy. Section 3 examines how the common monetary policy was implemented in the newest Economic and Monetary Union member states. Section 4 combines the current Romanian economy context with the present EMU member states opportunities. Section 5 presents a view of how the convergence criteria are being met or have any chance of being reached by the Romanian economy and what the measures needed to be taken by the authorities. Section 6 concludes the analysis by fixing the results of the possible adoption of euro by Romania. 


\section{The Present Economic Context in Romania}

Since the exchange rate liberalization in 1997, the monetary market in Romania was passed to free floating exchange. Moreover, in 2001, the currency market in Romania was changed by introducing the margins creeping courses, with a band width of $\pm 5 \%{ }^{1}$. Since 2005 the foreign exchange market in Romania has suffered a major reform, changing the strategy of exchange rate stability targeting with the inflation targeting objective. Thus, the Central Bank of Romania is currently addressing the price stability by intervening on the market through measures to limit the amount of currency in circulation while trying to encourage investment on the Romanian capital market. However, the privatization of the banking system was attempted in order to encourage the market competition, which would lead to a more attractive interest rate for investors. The monetary authority's policy worked very well until recently.

Unfortunately for the Romanian economy, the upward trend that was induced by the encouraging policies practiced by the central bank was interrupted by the confrontation with the new economic context, the financial crisis that emerged in the world in 2007, with severe adverse effects on the Romanian economy. In this context the pressure felt by the central bank led to the reduction of minimum reserve ratio due to the lack of liquidity on the market. If reducing the minimum reserve amounts in lei had no negative effects, but rather to help market operators, for foreign currency amounts the impact has almost been catastrophic. In these new circumstances, the commercial banks withdrew large sums from the market, returning them to the parent banks above, that had brought large amounts of currency in the national economy after buying the old Romanian banks.

Moreover, the political class carries a strong negative influence on the economic environment. In October 2009 the dismissal of the Romanian government caused a strong shock on the market, leading to currency depreciation by about $5 \%$ within only 3 days.

\section{New Member States of EMU - Evolution}

Greece, Slovakia, Slovenia and Portugal use euro in circulation, being among the Euro Area countries, but in the years preceding their accession to the area, the unemployment rate in these countries was very high. Thus, by $2004^{2}$, the unemployment rate reached the threshold of $8 \%$ in Portugal, exceeded this threshold in Greece and 12\% in Slovakia and Slovenia. Under these circumstances the unemployment rate in Romania, which in 2009 was forecasted by the NBR to be $8 \%{ }^{3}$ and in reality it reached the level of $7.8 \%{ }^{4}$ no longer seems as alarming. Also, during the same period, the rate of inflation in the listed countries hover around $10 \%$. If these values relate to the current situation in Romania we can conclude that, even during the current economic crisis, it no longer seems quite as serious. We can then determine the entry of the single currency target in the close future periods.

The states that have already adopted the single European currency are divided into two categories in terms of exchange rate arrangements. Thus, France, Belgium, Netherlands, Luxembourg, Austria and Denmark have succeeded in the period before the introduction of euro a relatively fixed maintain course towards the German currency. However, there is also the second camp, which includes countries like Italy, Britain, Ireland, Portugal and Spain that

\footnotetext{
${ }^{1}$ Cuaresma, C. J., Fidrmuc, J., Silgoner, M.A. (2008), Maria Antoinette Silgoner Fundamentals, the exchange rate and prospects for the current and future EU enlargements: evidence from Bulgaria, Croatia, Romania and Turkey, Empirica, 35, p. 198

2 Babecký, J. (2008), Aggregate Wage Flexibility in New EU Member States, AUCO Czech Economic Review, 2, p. 130

${ }^{3}$ Raport asupra stabilității financiare 2009, National Bank of Romania, p. 64

${ }^{4}$ Buletin lunar Secțiune Statistică (January 2010), National Bank of Romania, p. 49
} 
opted for a devaluation of currency that can help maintaining exchange ratio within $\pm 15 \%$, so a relatively high margin of fluctuation. Furthermore, Italy and Britain have come at certain times of ERM leaving loose speculation on the currency market ${ }^{5}$. In this situation, the inflation ratio in Romania in the recent years is not very alarming, even though some of the most developed countries in EU have announced that they have exceeded the global financial crisis, Romania remained behind at this point.

During the 90s, the Greek monetary policy was focused on achieving the level of inflation set by the Maastricht Treaty. Thus, the central bank based its intervention policy on the interest rates and its binding to the other Member States registered rates, for a more simple coordination of price stability.

In these circumstances, the national bank of Greece, managed to bring the economy on a positive trend and the results were favorable, exceeding many economists' hopes. The inflation rate suffered an interesting development during the year pre-accession the EMU inclusion. Thus, it decreased in the years before it: 4.5\% (1998), 2.1\% (1999), 2.9\% (2000) and in the year of inclusion, in 2001 it rose to $3.6 \%{ }^{6}$

There is however an interesting trend in the inflation rates in states which joined the euro zone, meaning that they have dropped in pre-inclusion years, following a slight increase of this indicator in the first year of single currency. We speak here of Portugal which experienced an evolution as follows: 1.9\% (1996), 2.2\% (1998), 2.1\% (1999), 2.8\% (2000), the last one being the year of adoption of the single currency, or Slovakia, where the inflation level reached 4.4\% (2007), 2.8\% (2008), 4.6\% (2009) ${ }^{8}$.

In Romania, the monetary policy practiced by NBR produced the expected results, and even more, in the years before the world financial crisis started manifesting went down even more than most optimistic economists expected, reaching below $5 \%$, specifically at $4.8 \%$, bringing us even closer than the achievements of the Greek economy. However, the inflation rate for 2009 increased up to $7.8 \%$ and unfortunately continues suffering frequent changes.

The 2001-2007 range produced a positive turn for the rapidly developing European countries, and the convergence rates achieved by these countries were generally higher than in previous periods. It the situation of Czech Republic, followed by Slovakia and Slovenia, while Poland has a much lower level.

\section{Romania and EMU in the New Economic Climate}

Economic and Monetary Union should learn from the past and try to pass over the obstacles that were faced by the old monetary unions, which reached the end of their existence. However, compared to them, EMU has several advantages which hopefully are to be exploited in a favorable way. For example, it is neither a purely international monetary union, nor a national one since the transfer of sovereignty is incomplete 9

A critical in the single monetary policy is played by the convergence criteria, required to be met by the states that want to incorporate in the euro area. Thus, price stability, convergence interest rate, exchange rate stability and budgetary discipline are of main importance and priority for any such state.

Joining the EMU has several inconveniences of which the most important ones are losing the autonomy of the monetary and fiscal policy. For a state in development as is the case of Romania, it may have beneficial effects on one side and adverse effects on the other. Perhaps the negative side predominates, both in the conditions in which the Romanian economy has

\footnotetext{
${ }^{5}$ Antal, J., Holub T. (2007), Exchange Rate Arrangements Prior to Euro Adoptio, AUCO Czech

Economic Review, 3, p. 314

${ }^{6} \mathrm{http} / / /$ www.indexmundi.com/greece/inflation_rate_(consumer_prices).html

${ }^{7} \mathrm{http}: / /$ www.indexmundi.com/portugal/inflation_rate_(consumer_prices).html

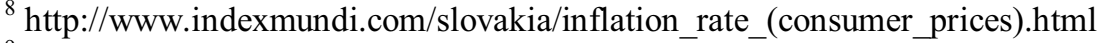

${ }^{9}$ Bordo, M., James, H. (2008), A long term perspective on the euro, Economic papers, 307, p. 27
} 
recorded upward trend based on state intervention on fiscal policy and especially the central bank's interventions in the monetary policy. Thus, "triangle of inconsistencies" as I called Sahoko Kaji in 2004 in his The euro, the enlarged EU and Asia is being shaped, triangle composed of three goals: monetary policy autonomy, exchange rate stability and free movement of capital. These three objectives of the EMU can not be achieved simultaneously. This could cause instability, imbalance, with negative effects on an economy like that of Romania, knowing that the whole movement of capital was coordinated by the monetary policy pursued by the NBR. Most capital inflows in the 2005-2007 period, so before the beginning of the financial crisis, was based on amounts sent by the Romanian workers working abroad and on speculative capital inflows into the country due to attractive interest rates. Moreover, following the privatization of banks, capital inflows was relieved, even those entering large amounts in the Romanian economy, attracted the highest degree of fructification and therefore better recovery of resources. However, after 2007, they began to withdraw the amounts invested on the Romanian market, being forced by the liquidity crisis that the parent banks were facing. Moreover, the NBR minimum reserve rate reduction policy, for the foreign currency amounts particularly, have helped to increase the amounts withdrawn from the Romanian money market, thus leading to an overheating of the lack of liquidity.

In Romania's case, the main problem is that of meeting the conditions of budgetary discipline. Unfortunately, the policies promoted by the government for ending the financial crisis need to be explored more extensively before implementation, which did not happen with the Romanian government. Even more, conflicts have arisen in recent times and winding up in recent days led to a worsening economic situation. Also, contracting the credit from the International Monetary Fund has brought new conditions and new needs in order for them to be fulfilled. The new targets, imposed by this institution, made it necessary for some changes to be made to the budget. Nevertheless, increasing taxes, mass redundancies and reduced public spending by reducing the amount for productive activities encouraging are not the appropriate measures for stopping an economic crisis. In these new circumstances, the national bank is seen even more compelled to intervene in the market to counter the imbalances caused by panic induced by the events produced.

The effects of EU enlargement on banking systems, of both the new and old member states should be favorable. Thus, traditional banks in developed countries of the union may choose to develop their business by expanding into new Member States ${ }^{10}$.

The level at which domestic banks are taken over by powerful international banks is widely regarded as a favorable factor for healthy development of the banking system in any state. Accordingly, after 1991 Romania has targeted the banking system privatization reform for the state banks, which led to the current situation in which most banks operating in the market are either indigenous banks that were taken by international giants or branches of some such banks.

So while in some countries such as Bulgaria, Croatia, Latvia a large part of the national banks in the system have domestic capital (about 50\% in the last two), in other states the level is much lower. It is Poland, Hungary, Czech and even Romania situation, where this indicator stands at around $20 \%$, while the remaining $80 \%$ are foreign-owned banks. Favorable effects were felt during the previous periods in the context of flooding local markets with capital for investment coming from outside the economy, leading to an acceleration of growth, but during the current crisis the effects were completely negative. We can talk about Romania here, where significant amounts of increased liquidity have been withdrawn due to the great needs of money faced by the parent banks.

The differences between the newly entered states of the union and the much older traditional states are unfortunately very high, which leads to a discrepancy in understanding the

\footnotetext{
${ }^{10}$ Passera, C. (2004), The Enlarged EU: Economic Integration, Financial Development, and Business Opportunities for Foreign Banks, Transition Studies Review, 11(3), p. 27
} 
monetary policy needed to be implemented in both cases $^{11}$, perfectly true and producing greater damage to the new states and less to the old developed ones.

Therefore, the standards imposed by Germany and France have had negative effects on less economically developed countries. It is here where Portugal has been affected by the new rules for growth and stability formulated by the two pillar states of the European Union.

\section{Convergence Criteria Indicator Levels for Romania}

As I mentioned during the previous section, the convergence criteria are: price stability, convergence rate, budgetary discipline and exchange rate stability. In the following paragraphs we will review how the levels of the specific indicators for each criterion are met. Price stability as a criterion implies that the inflation rate should not exceed by more then $1.5 \%$ the average rate of the 3 member states of EU that had the best performance in this area.

Table nr. 1 Inflation Rate Criterion in 2009

\begin{tabular}{|c|c|}
\hline Member State & Inflation rate (2009) \\
\hline Netherlands & $2.50 \%$ \\
\hline Portugal & $2.60 \%$ \\
\hline Germany & $2.70 \%$ \\
\hline Average first $\mathbf{3}$ & $\mathbf{2 . 6 0 \%}$ \\
\hline Average EU & $5.36 \%$ \\
\hline Romania & $\mathbf{7 . 8 0 \%}$ \\
\hline \multicolumn{2}{|c|}{ (Source: www.indexmundi.com) }
\end{tabular}

As can be seen from the table above the inflation rate in Romania is $5.2 \%$ higher than the average inflation rate registered in Netherlands, Portugal and Germany, which are states recording the lowest level of the indicator across the EU. Moreover, the inflation registered in Romania in 2009 exceeded by $2.44 \%$ the average inflation rate for all EU countries. Under these circumstances we can conclude that this criterion is far from being achieved.

The interest rate convergence criterion requires that long-term interest rate can not exceed the average of the recorded results within the 3 states that achieved the best performance by more than $2 \%$ in the previous year.

Table nr. 2 Long Term Interest Rate in the European Union

\begin{tabular}{|c|c|c|c|c|c|c|c|c|c|c|c|}
\hline Countries & Feb & Mar & Apr & May & Jun & Jul & Aug & Sep & Oct & Nov & Dec \\
\hline Germany & $\mathbf{3 . 1 3}$ & $\mathbf{3 . 0 2}$ & $\mathbf{3 . 1 3}$ & $\mathbf{3 . 3 7}$ & $\mathbf{3 . 4 7}$ & $\mathbf{3 . 3 4}$ & $\mathbf{3 . 3 1}$ & $\mathbf{3 . 2 6}$ & $\mathbf{3 . 2 1}$ & $\mathbf{3 . 2 2}$ & $\mathbf{3 . 1 4}$ \\
\hline Sweden & $\mathbf{2 . 9 3}$ & $\mathbf{2 . 9 4}$ & 3.18 & 3.57 & 3.62 & 3.37 & 3.45 & 3.38 & 3.25 & 3.27 & 3.24 \\
\hline UK & $\mathbf{3 . 2 3}$ & $\mathbf{3 . 0 0}$ & $\mathbf{3 . 1 6}$ & $\mathbf{3 . 4 1}$ & $\mathbf{3 . 5 2}$ & $\mathbf{3 . 5 5}$ & $\mathbf{3 . 4 5}$ & $\mathbf{3 . 4 2}$ & 3.34 & $\mathbf{3 . 4 6}$ & $\mathbf{3 . 6 0}$ \\
\hline Average first 3 & $\mathbf{3 . 1 0}$ & $\mathbf{2 . 9 9}$ & $\mathbf{3 . 1 6}$ & $\mathbf{3 . 4 5}$ & $\mathbf{3 . 5 4}$ & $\mathbf{3 . 4 2}$ & $\mathbf{3 . 4 0}$ & 3.35 & 3.27 & $\mathbf{3 . 3 2}$ & $\mathbf{3 . 3 3}$ \\
\hline Average EU & 5.50 & 5.59 & 5.54 & 5.49 & 5.79 & 5.60 & 5.44 & 5.38 & 5.22 & 5.16 & 4.99 \\
\hline Romania & $\mathbf{8 . 4 2}$ & $\mathbf{9 . 3 8}$ & $\mathbf{9 . 7 7}$ & $\mathbf{8 . 3 2}$ & $\mathbf{1 1 . 3 0}$ & $\mathbf{1 1 . 4 6}$ & $\mathbf{1 1 . 4 6}$ & $\mathbf{1 1 . 0 0}$ & $\mathbf{9 . 1 3}$ & $\mathbf{8 . 2 4}$ & $\mathbf{8 . 6 6}$ \\
\hline \multicolumn{8}{c}{ (Sources: ECB and European Commission) }
\end{tabular}

\footnotetext{
${ }^{11}$ Poghosyan, T. (2009), Are "new" and "old" EU members becoming more financially integrated? A threshold cointegration analysis, International Economics and Economic Policy, 6, pages: 279
} 
As can be seen from the table, this criterion can not be considered done as well. The difference between the Romanian long-term interest rates and the average result in 3 the European countries considered the best in this domain in the analyzed year is 5-6\% instead of $2 \%$ that is the maximum admitted. A significant difference can be found from the average long-term interest in the whole Union as well. In this situation the difference is smaller (2.9$5.6 \%$ ) but still very far from the value we need.

The budgetary discipline criterion involves two lines of analysis. On the one hand the budget deficit should be taken into consideration. At the end of the previous year should not exceed more than $3 \%$ of GDP and on the other hand the government debt should not exceed $60 \%$ of GDP. These values are considered good even if the results have not been the ones asked for, but they are very close to the target. The following table contains data about these indicators.

Table nr. 3 Bugetary Discipline Indicators

\begin{tabular}{|c|c|c|c|}
\hline 2009 & GDP & Government deficit & Public Debt \\
\hline Quantum (mil. RON) & 505503.0 & 36400.6 & 148055.1 \\
\hline Percent in GDP & $100 \%$ & $7.2 \%$ & $29.29 \%$ \\
\hline \multicolumn{2}{|c}{ (Source:NBR and MFP) } \\
\hline
\end{tabular}

As we can see in the table, we are at two sides of the same rock. The public debt is lower then $60 \%$ of the GDP so this condition is met. But the criterion is far from being achieved since the buget deficit is more then 2 times bigger than it should be.

The exchange rate stability criterion requires that the State willing to join EMU to have been a member of the exchange rate mechanism (ERM II) for at least two consecutive years without a record of currency depreciation in this period. Romania does not meet these conditions, since it is not a member of ERM II, but the authorities are expressing the desire of being included in the 2010-2012 range.

\section{Conclusions}

Throughout the paper we have analyzed the current economic context in Romania, how the monetary policy were implemented before integration of new Member States in EMU and a comparison between the situation in these countries at these times and the current situation in Romania. We can say here that the Romanian economy is not currently ready for such a high step, especially when thinking about the necessity of interventions on the national money market.

From the perspective of membership criteria we can be say that while before the global financial crisis started its bad influence we were located on a comfortable position, at present this can no longer be said. Price stability is not met, accounting to the inflation rate increasing sharply from month to month. The interest rate convergence can not be mentioned because of the large discrepancies in the exchange rates evolution and high inflation. All these lead us to conclude that the interest rate is necessary to be raised to cover all the risks the banking sector is facing. The stability of exchange rates is affected by an accumulation of factors coming from both the political medium and the necessity of other measures needed to be imposed in order to influence the monetary policy for touching this criterion. Budgetary discipline forces the state to take measures with negative effects over the national economic environment.

The conclusions are simple and as clear as possible. The National Bank of Romania interventions by monetary policy, were in the past and are currently of a high performance, even when the facing financial crisis has aggravated the economic situation in general. Moreover, the political side has negative influences on the economy, mostly through shocks produced in recent months. In these circumstances, the National Bank is forced to 
make further efforts to stabilize the national currency due to devaluation forced population caused by panic induced by the political chaos.

However, a possible implementation of the single monetary policy could have negative effects on the Romanian economy at present, especially because the National Bank will not have the authority to intervene on the market to defend the national currency, inflation targeting and indirectly boost economy practiced by the credit policy. The most pessimistic version of the story is that of a national collapse following the shutdown of the NBR beneficial interventions.

\section{Bibliography}

1. Antal, J., Holub T. (2007), Exchange Rate Arrangements Prior to Euro Adoptio, AUCO Czech Economic Review, 3, pages: 312-323

2. Arghyrou, M. G. (2009), Monetary policy before and after the euro: evidence from Greece, Empirical Economist, 36, pages: 621-643

3. Aron, O. (2008), The Impact of Europeanization upon Party Systems in Slovakia and Romania, Transition Studies Review, 15, pages: 273-280

4. Babecký, J. (2008), Aggregate Wage Flexibility in New EU Member States, AUCO Czech Economic Review, 2, pages: 123-145

5. Belke, A., Spies, J.(2008), Enlarging the EMU to the east: what effects on trade?, Empirica, 35, pages: $369-389$

6. Bordo, M., James, H. (2008), A long term perspective on the euro, Economic papers, 307, pages: 130

7. Cuaresma, C. J., Fidrmuc, J., Silgoner, M.A. (2008), Maria Antoinette Silgoner Fundamentals, the exchange rate and prospects for the current and future EU enlargements: evidence from Bulgaria, Croatia, Romania and Turkey, Empirica, 35, pages: 195-211

8. Gärling, T., Thøgersen, J. (2007), Effects of the Euro Changeover on Consumer Behaviour: Introduction to the Special Issue, Journal of Consumer Policy, 30, pages: 303-311

9. Katainen, J. (2009), Bringing economic growth back to the European Union, European View, 8, pages: $47-52$

10. Passera, C. (2004), The Enlarged EU: Economic Integration, Financial Development, and Business Opportunities for Foreign Banks, Transition Studies Review, 11(3), pages: 17-27

11.Poghosyan, T. (2009), Are "new" and "old" EU members becoming more financially integrated? A threshold cointegration analysis, International Economics and Economic Policy, 6, pages: 259-281

12. Ryan, C., Horsewood, N. (2009), The role of banks in financial integration: evidence from new EU members, International Economics and Economic Policy, 6, pages: 235-258

13. Sahoko, K. (2004), The euro, the enlarged EU and Asia, Asia Europe Journal, 2, pages: 399-414

14.Žd'árek, V. (2009), Challenges for the new EU member states on the road to the Eurozone, International Economics and Economic Policy, 6, pages: 157-177

15.Buletin lunar Secțiune Statistică (January 2010), National Bank of Romania

16. Raport asupra stabilității financiare 2009, National Bank of Romania

17. www.indexmundi.com

18. www.mfinante.ro 